Safa Garayev

\author{
Institute of Folklore, National Academy of Science of Azarbaijan \\ safaqara@mail.ru
}

\title{
The Oedipus Tale Type in Azerbaijani: Folklore and its Socio-Psychological Semantics
}

\begin{abstract}
In this article, I analyze tales collected from Azerbaijani territories from a psycho-semantic perspective, specifically pertaining to the Oedipus tale type (AT: 931, 933). The incest taboo, a common theme in Azerbaijani society, is discouraged in these tales through symbolic behaviors. In these tales, which were collected in different Azerbaijani territories at different times, the transgression of the taboo of incest firstly happens between sisters and brothers, later between mothers and sons. When we approach the fairy tale plots presented in the context of the Oedipus complex, it becomes clear that these fairy tales are also organized on the basis of the son's point of view. This is evident in the tales because of their descriptions of the father - a common character in the Oedipus tale type - as the culprit of all anti-social and unethical problems. In the texts I present, the heroes of the tales generally derive from the disruption of the incest taboo between the sister and the brother, who has been left to die. I argue that the baby born as a result of dismantling the incest taboo-being removed from the chain (or from the family environment) of the social relations by the parents to be left to die and later living and not recognizing his mother-is portrayed as the main fact in the explanation of the events' semantics.
\end{abstract}

Keywords: Oedipus tale type, incest taboo, son's point of view

Introduction

The 931st plot in the Aarne-Thompson catalogue is a primary focus in modern folklore studies. This plot, collected from the different regions of the world, is also called Oedipus tale type ${ }^{1}$ based on its content, conflict level, and inherent meaning, which is similar to the drama "Oedipus the King" by Sophocles. It

${ }^{1}$ It is important to note that the Oedipus tale type has been drawn into Folklore research of many different groups and regions, such as Gypsies (Karpati 1995, 23-28), Alur (Southall 1995, 35-39) Bushman (Biesele 1995, 39-45), Oceania (Lessa 1995, 
should be noted that in 1897, Sigmund Freud wrote the first account of psychological conflict - which came to be known as the "Oedipus complex"-in his letter to the doctor Wilhelm Fliess from Berlin. In that letter, he wrote about the child's love for his mother and the child's jealousness of his father, grounding his interpretation in the drama "Oedipus the King" by Sophocles:

I have found, in my own case too, [the phenomenon of] being in love with my mother and jealous of my father, and I now consider it a universal event in early childhood, even if not so early as in children who have been made hysterical. (Similar to the invention of parentage [family romance] in paranoia-heroes, founders of religion). If this is so, we can understand the gripping power of Oedipus Rex, in spite of all the objections that reason raises against the presupposition of fate; and we can understand why the later "drama of fate" was bound to fail so miserably. (Masson 1985, 271)

Freud named his famous theory the "Oedipus Complex" in 1910, and according to this theory, a son's psychological imperatives revolve around his love for his mother and the corresponding jealousy he feels for his father, who is his enemy or rival. Freud's theory produced two results: (1) Freud explained the psychosomatic basis of human drives and (2) Freud discovered the importance of emotional-internal conflict, necessary for the development dynamics of human psychology. The complex choosing the target of the explanation of the emotional reality of the human in the first periods developing little by little became one of the main models for explaining social-public relations in an anthropological context. Folkloristics remains one of the scientific branches dedicated to investigating psychoanalytic theory widely, and at this time studying the psycho-semantic essence of different cultural contexts, the implications of conflicts, and the nuances ascertained in the process of turning psychological reality into textual reality form the basis of these investigations.

\section{Research Materials and Methods}

Taking into consideration the special interest placed in investigating the 931st and 933rd tale types from the Aarne-Thompson catalogue, I aim to analyze the variants of this tale type that I have collected during my research in the Azerbaijani territories. Before analyzing the plots and motifs in these tales, I will provide a basic plot summary of both texts. One variant of a tale including the incest motif is the Azerbaijani tale "Chay avarasi" ("The River Loafer"), published in 1890 in the journal SMOMPK $(1890,184-189)$. This tale was collected from a Christian resident of Azerbaijan. The plot of the tale is as follows:

56-76), Burma (Spiro 1995, 203-215), and Finn (Eerola 2019, 103-111)—works that have discovered nuanced meaning in this tale type. 
After the death of a just king and most of his family, only his little son and daughter survive. Because the king was fair, his former subjects decide to rule on behalf of his son and daughter until they come of age. One day, Satan seduces the brother and the sister living together in their father's palace. The sister becomes pregnant with her brother's child and eventually bears a son. Not wanting their child, the sister and the brother throw the baby into the great river. In order to repent, the brother goes to Jerusalem while the sister continues to rule the kingdom.

A miller finds the baby in the river and brings him in. The child comes to be known as "Chay avarasi" ("The River Loafer") by his peers. The miller does not want to tell the child the truth about his upbringing, but the child protests and eventually the miller gives in. The miller confesses that he found the child as a baby in the river. More fully understanding his past, the child embarks on a journey to learn more about himself.

Travelling far and wide, Chay avarasi arrives in a kingdom ruled by a woman. Because ruling the kingdom is very difficult for the queen, the country's populace decides to marry her to a man who will take her place as ruler. Chay avarasi voices his desire to fulfill this position. The common people gather in the square and throw lots to display their discontent with the queen's leadership and with her potential successors, including Chay avarasi. The lots show Chay avarasi that at first the population did not want him to be their ruler because they thought that a strange man with an unfamiliar background could not be their king. However, Chay avarasi persists and, thinking that he was sent by God, the populace marries him to the queen, ultimately crowing him king. The new king is humanistic and rules the kingdom fairly. The king and queen love each other very much and have two children together.

One day, the king sees the queen open a box with a key and take a piece of paper out of it, read the paper, and begin crying before putting the paper back into the box and closing it. When the king asks the queen about this incident, the queen denies that it happened. The king insists that he must read the piece of paper and asks for the key incessantly. In response, the queen says she has lost the key. Unhappy with this reply, the king breaks the box open and reads the piece of paper. The paper contains a story about a baby who was born from the marriage of a brother and a sister whose parents threw the baby into a river. Understanding the implications of this story, the king and the queen realize that they are mother and son. The king says to the queen that they had not willfully committed a sin given the way in which events transpired. In order to wash away his sin, the king puts on his old clothes and departs the kingdom and the queen.

After leaving the kingdom, Chay avarasi comes across a magnificent house near the sea. Hungry and tired, he asks the owner of the house for shelter. The owner provides Chay avarasi with a room, and Chay avarasi proceeds to explain his story to his host. He then asks the host if there exists an island in the sea on which nobody lives because he wants to go and pray there until the end of his life. 
The host answers that he knows of such an island and at Chay avarasi's request, the host takes him there. After arriving on the island, Chay avarasi asks the host to bind him with a locked chain in a cave and throw the key into the sea. Chay avarasi says that if the key floats on the surface of the water, it would mean that all of his sins are absolved. The host fulfills his requests and returns to his house.

A long time passes, so much so that the host has forgotten about leaving Chay avarasi on the island. One day, the catholicon of a country dies. The population of that country wants to choose a new catholicon, so they throw the lots and it shows the sea. In order to find the new catholicon, twenty people come to the host and ask him about the person living near the sea. Suddenly, the host remembers binding Chay avarasi with a chain and leaving him on the island. He looks through his notebook and determines that thirty-two years have passed. In spite of the time that has passed, the group decides to go to the island. Arriving on the island, the host tells his slaves to go fishing and prepare a meal for them while he and the twenty people go to the cave. Entering the cave, the host sees that Chay avarasi has gotten older and that the food left near him many years before remains. Greeting and kissing his hands, the twenty people in search of a new leader tell Chay avarasi that they want him to be their catholicon. Suddenly, one of the slaves enters the cave and announces that he has found a key in the mouth of a fish he caught. Hearing this, Chay avarasi begins to cry that his sins have been forgiven by God. He agrees to go along with the group.

The twenty people bring Chay avarasi to their land and anoint him their catholicon. From many parts of the world people come to listen to his preaching and find comfort. His mother and former wife also comes to ask him to forgive her sins. The catholicon does not explicitly inform her that he has forgiven her sins.

The other tale embodying the Oedipus tale type was published in the book West Group Dialects and Accents of the Azerbaijani Language, which focuses on dialects (Rustamov and Shiraliyev 1967, 281). This tale was collected from a Muslim resident of Azerbaijan. The tale's plot is as follows:

One day a king asks his vizier "Do you find it more pleasant to speak with someone when they are drunk or when they are sober?" The vizier responds that he cannot answer the question at that time. The king and the vizier go hunting. They walk until night falls. Upon the vizier's recommendation, they decide to spend the night in a local house. The vizier finds a house and knocks on the door, which is opened by a girl whom the vizier asks if he could stay for a night as a guest. The girl brings this request to the owner. The hostess agrees, believing her guest is a gift from God, but she tells the guest not to divulge anything about what he will see in her house. Entering the first room, the vizier sees a grave in the corner of the room. The grave is flanked by candlesticks and has a lamp directly above it. Opening the door to a second room, the vizier sees another grave in the corner of the room. This grave also has candlesticks on either side and a lamp directly above it. The vizier opens the door to a third room - the hostess' room. The hostess invites the vizier to eat supper, after which he goes to bed. 
The vizier tells the king about everything he saw in the house and invites the king to see it with his own eyes. The vizier once again tells the host that he would like to stay for a night, but this time with his brother. The hostess accepts them as guests from God and tells them not to speak of anything that they see in the house.

After supper, the king asks about the graves in the house, making the hostess very angry. Because her guests broke their agreement, the hostess calls an executioner to kill them. Suddenly, the guests take off their hunting clothes and the hostess realizes that they are the king and the vizier. The executioner states that he does not want to kill the king and ignores the hostess' command. Recognizing the king, the hostess begins to explain the story behind the graves.

She says, "The city's swindlers took my brother to a drinking party. My brother returned to the house late at night and he was extremely drunk. He encroached on me that night. In the morning, I told him about what had happened and, remembering everything, he took a dagger and killed himself. Being afraid of how people would respond to me giving birth to the baby, I took the child and went into the forest; I put the baby on the stump and left him there. As it turns out, some woodcutters found the baby and took him in. One day, we saw each other and - not understanding our connection-fell in love and were married. Sometime after our wedding, he was taking a bath and I saw a birthmark on his shoulder. I explained to my son his past and in response he killed himself. Now every evening nine girls come to my house to share my grief; we weep with sorrow and then they leave."Remembering the question the king asked about preferring to speak with people who are drunk or sober, the vizier tells the king that this is the answer to his question, saying "Your Honor, you asked me if it is more pleasant to speak with a person who is drunk or a person who is sober; our hostess has answered this question."

Analyzing these tales collected in different times, the similarity in their content and semantic essence is obvious. Both of the tales include accounts of incest, meaning they establish unique information in our understanding of the psycho-semantic essence of this problem. First, it should be noted that incest is extremely taboo in Azerbaijani society, so there is very little information available regarding this issue. However, many Azerbaijani tales and legends provide scholars with an opportunity to look at this problem through a semantic lens. For example, many tales belong to the 512B tale type in the Aarne-Thompson catalogue; that is, these tales demonstrate the dismantling of the incest taboo in the context of the father's desires. Besides this, in many variants of the legend "Giz galasi" ("Maiden Tower") — which is very popular in Azerbaijanthe incest motif of the father being in love with his daughter is reflected very clearly. But in both of the stories, the father's inclination towards incest is not realized and instead he is punished with death. It is clear from these tales that the transgression of the incest taboo in social relations - even hypothetically in folk thinking - is a behavioral act equivalent to the punishment of death. But in 
mythical texts such as the Biblical story of Adam and Eve, the perpetrators of incestuous acts are not punished by death. Alan Dundes writes: "If Eve is born from Adam's body, then she in some sense might be considered Adam's daughter. In that case, it would be father-daughter incest" (Dundes 1997, 85).

Being perceived as a part of nature, the first human couple in Christian mythology - operating in a period in which social relations had not yet been established - do not face such punishment. It should be noted that in order to avoid the supposition of transgressing the incest taboo in social relations, there are many realized symbolic acts and behaviors, but this article does not discuss this topic widely. In Turkey, for Turkish members of the Oghuz group - a group that also includes Azerbaijan Turks - customs can be very important in displaying sensitivity to the incest taboo. The marriage custom called "taygeldi" embraces relations between stepbrothers and stepsisters. In this type of marriage, which met very rarely, the marriage act of the stepsiblings (a widower's child with a widow's child) and the widow and widower's own marriage are realized. For example, "In such marriages, generally, children are married firstly and then the widow and widower (the parents) are married" (Abali 2011, 82). Furthermore, "According to a belief, if before a stepsiblings' marriage the widow and widower's marriage is realized it is said: 'The stepsiblings will not have children.' Due to the other thought, when the widow and widower are married before the stepsiblings the stepchildren will be considered as a sister and a brother; that is why the stepsiblings must be married before them" (Balaman 2002, 45). As demonstrated, in order to avoid the transgression of the incest taboo in marriages that do not consist of blood relatives, sensitivity is emphasized. Before not looking through the content of many symbolic behaviors realized during the marriage in order to disorder the incest taboo we can say that this prohibition (taboo) underpins many symbolic behavior actions in traditions of the Azerbaijan nation as in all human societies. Because the incest taboo is one of the norm-defining phenomena in social behavior and relationship ties, it has been declared "holy" - one of the most important relationship considerations in the world. But in the two tales mentioned above, we witness the realization of incestuous relations prohibited by human societies, which creates a situation in which the characters must investigate the implications of incest. Since incest is vilified in social life, society emphasizes the importance of protecting this prohibition in both behaviors and norms. As such, because the transgression of the incest taboo is the main commonality in the texts mentioned above, and because each text emphatically displays the importance of dismantling incestuous practices, further explanation is necessary.

In the tales mentioned above, the incest taboo is disordered in the story's social environment. Punishment for this transgression is dealt not by society, but instead by humans. Before analyzing this phenomenon in the context of incestuous relationships, it should be mentioned that "putting a curse" on someone (lan- 
guage used to emphasize perseverance or persuasiveness) is a phrase commonly used in Turkish conversations. In many cases, this phrase refers to a person convincing themselves to do something; for example, "If I do not do that work let my mother be my wife." Just as incest is seen as punishment in the above-mentioned tales, modern language uses the idea of incestuous relationships to demonstrate the importance of completing a given task. In this case, the person "cursing" themselves or someone else acknowledges the difficulty of the goal-something that must be completed if the person is to avoid sin. So, the abusing person's disordering probability of his aim turning into the taboo together with the incest is also mentioned. Such word combinations, in fact, aim to bring attention to the insistence of the person "giving a curse" and the impossibility of disordering this thought (as the transgression of the incest taboo is impossible). Though the semantics of this word combination in social context provides an opportunity to explain the abuse text, this text's psycho-semantic essence in the Freudian context and the explanation of turning into language the form of "abusing oneself," passing from the taboo borders of consciousness (even in the negative form) of this relation, can show the different scenery. Here, the secret wish to the mother turning into the negative form and so "deceiving" the social censorship becoming topical in the aggressive situations, in the negative form is the language formula and the folklore event. But here one of the interesting points is the conformity of the relation level in this abuse seen as "the punishment to one's own self" and the relation levels of the tale texts introduced by us.

The texts mentioned above are different from the drama "Oedipus" by Sophocles. In that plot, after learning about the priest killing the father of the baby and marrying his mother, Oedipus is left to die. But it is not until the end of the story that the hero is given this information. In their investigation of "Oedipus," some academics have neglected to frame this story with the father as the enemy regarding the love relationship between the son and the mother. Alan Dundes has spoken on this topic at length, particularly regarding Stanley Hall's analysis of Oedipus. Stanley Hall does not believe this plot exemplifies the Oedipus complex because Oedipus does not recognize his father and mother. According to Stanley Hall, this means Oedipus's father cannot assume the "enemy" position in the Oedipus complex, as Oedipus does not know of his relationship with his love interest. In response to Hall's assertion, Dundes says Hall does not understand the nature of Freud's conception, arguing

We have already noted that Hall did not accept the validity of the Oedipus complex on the grounds that Oedipus did not know his father or mother. It is pretty clear from this that Hall did not have a firm grasp of the nature of the Freudian unconscious. Folklore offers a socially sanctioned outlet for the expression of often taboo ideas. Hence it is essential that Oedipus did not know (consciously) that he was killing his father and marrying his mother. If he did, there would be no plot, no drama (Dundes 1997, 7). 
A similar idea applies to the tales introduced above. Ultimately, this means the boy in the tale does not need to recognize his mother before their marriage for the story to fall under the Oedipal tale type. In this case, Alan Dundes's idea is especially pertinent: folklore offers a model to personify the thoughts and ideas that are taboo in society, one of which is Oedipal desires. In order to remove social taboos, the incestuous desires of the boy make him unrecognizable to his parents, further obfuscating his social placement. If this was not the case, incestuous desires not getting over the social taboo could not comprise the folklore plot and the folklore text.

\section{Discussion}

In the Oedipal style of the tales mentioned above, the guilty father's absence from the mother when the son marries his mother should be addressed. In "Chay avarasi," when the son marries his mother, the father- having transgressed the incest taboo-leaves his wife (or his sister) for Jerusalem in order to resolve his sins, but in the second text, the father-who has been drunkenly intimate with his sister-kills himself. Such plot points must be examined as the structure of the Oedipus complex according to psycho-semantic perspectives. In both tales, the reaction resulting from incestuous practices connects the protagonist solely with the mother. In both of these tales the heroes fall in love with their mothers without knowing them. Here, to marry one's mother in the context of "obscurity," "unrecognizability" must be understood as the model offered to express the taboo surrounding Oedipal desires in folklore's social context.

Analyzing the tales, it is clear that incestuous desires have been summarized in two points: (1) In the sections introducing "obscurity" and "unrecognizability" to the relationships between mother and son, we become witnesses to the actualization of Oedipal desires and (2) "obscurity" and "unrecognizability" disappear in the relationships between mother and son after they understand the reality of their situations and the social norms (particularly punishment) attached to those situations.

In the model of "obscurity" and "unrecognizability" of folklore, the opportunity creates the manifestation of Oedipal desires, leading to happiness for all parties involved. But the calmness arising from the actualizing of Oedipal desires ends when the mother and the son realize the reality of their relationship. Discovering that they are mother and son, the husband and wife must determine how to approach their socially unacceptable relationship. As a rule, discovering the reality of a situation in folklore is accompanied by the appearance of something illuminating information from the past. In the first tale, the letter becomes the illuminating object and in the second tale, the son's birthmark clar- 
ifies the situation. In both tales, the incestuous couples split as a result of their realization. Another interesting aspect of both tales is that only the child leaves once their incestuous relationship is revealed. In the first tale, the child maroons himself in an island cave, and in the second, the child kills himself. This is not accidental. The appearance of the Oedipus complex on the basis of the emotional experiences of the son is completed just punishing himself after the realities revealed. In the logic of the tales, the side of the relationship revealing their sin ultimately is punished at the end. That is why word combinations like "to kill himself/herself" and "to maroon himself/herself in the cave" must be accepted as the symbolic equivalents of punishment for Oedipal desires in the tales.

The most important aspect of the tales mentioned above is the double incest that takes place, which differentiates these stories from the drama "King Oedipus." In the tales, we see that before the transgression of the incest taboo between the son and the mother, this taboo has been disordered between the sister and the brother. In turn, it led the first tale's protagonist to leave his sister for Jerusalem in order to be forgiven, and in the second tale it caused the brother to kill himself. As I have mentioned above, though the act of transgressing the incest taboo between the sister and the brother has the same semantic essence as the act of transgressing the incest taboo between the mother and the son, the conditions under which they realize their respective situations differ. This means the "obscure" and "unrecognizable" taboo that is actualized in the tale between the sister and the brother is described in the text as a case of disordering definite social relations. In the tale "Chay avarasi," it is labeled as being "seduced by Satan," but in the second tale the taboo is explained with the phrase, "the swindlers made the brother drunk." As mentioned above, in the case of transgressing the incest taboo between the sister and the brother (or not having this taboo from the beginning), the culture does not inflict a punishment similar to that of the first Biblical couple Adam and Eve. Unlike that defending the incest taboo between the brother and the sister is one of the strictest norms in the social norms. But expressions like being "seduced by Satan" and "the swindlers made the brother drunk" serve to characterize this taboo transgression as a deviant action. In other words, with the help of these expressions, the party transgressing the taboo is labeled as having gone beyond the social norms, and the act of transgressing the taboo is brought to attention as the cause of the disturbing behaviors of the same man undergoing the different extraneous influences. Here, the most interesting point is determining the connection with and the attitude behind transgressing the taboo between the mother and the son compared with transgressing the taboo between the sister and the brother. Investigations in the realm of psychoanalytic perspectives demonstrate that texts about transgression of the taboo between son and mother are mostly formed on the basis of the "son's point of view." In the tales, this leads to describing the father as the guilty party, shown as the result of "projective inversion." In this case, if we consider the first tale from 
the theoretical perspective of the "son's point of view" archetype, the essence of the problem becomes clearer. It should also be noted that in the text, the position expression may not form the timing with the development dynamics of the plot. In other words, in the tales, the expression of the son's point of view does not begin to actualize its presence in the text. The son's point of view leading to projective inversion (as a result of projective inversion, the son's guilt arising from his incestuous desires is introduced as his father's guilt) derives from the introduction of the father as the guilty party at the beginning of the story. The result of this point of view is that the father becomes the main functionary of taboo transgressing behavior between the sister and the brother and is ultimately demonized because of society's norms. According to the semantic content, it serves replacing in the acuter censure position the father's guilt covering to the "obscurity" and "unrecognizability" actualized than the incest transgressing relation between the mother and the son.

There is another underlying problem addressed in the tales mentioned above. As many are aware, in Azerbaijan, with Turks who have the father family peculiarity, the relationship corresponds to a model called "descriptive system of kinship" by anthropologists. In this system, the brother of any person's mother (maternal uncle), the father's brother (paternal uncle), and his father are expressed with different relationship terms. At the same time, the father's sister (paternal aunt), the mother's sister (maternal aunt), and the mother are also referred to under different names (Havilland 2008, 529). Observing the tales mentioned above, we become aware of the collapsing of the characteristic family and relationship system for social norms. From the text, we see that as a result of transgressing the incest taboo, the relationship attitudes inherent in social norms lose their meaning and power. In both tales, as a result of transgression of the incest taboo by the brother and the sister, children are born, and later these children marry their mothers, leading to the following scenario: a "father" who is also an uncle (the mother's brother) and a "mother" who is also an aunt (the father's sister). This chaotic situation in terms of social norms affirms "the incest taboo" as being the main status-determining social principle. From the stories, we see that the transgression of this taboo can lead to the disruption of the fundamental societal order. In this case, the Oedipus tale type (AT: 931, 933) in the Aarne-Thompson catalogue can be described as the text providing a reflection of the social order-the description of social chaos.

\section{Conclusion}

One of the most important functions of folklore is to present definite models and methods in order to identify anti-social and unethical feelings, thoughts, and behaviors. In this case, the expression of the incest taboo considering the 
taboo for the social norms can be estimated in the model explained above in this function context of folklore. As a result of this investigation, it is clear that the poetics of the tales mentioned above has been formed on the basis of "the son's point of view." In addition, it demonstrates the semantic difference between the first taboo transgression (the sister and the brother) and the second taboo transgression in the investigated texts. Through knowing one another as members of the social relation chain, the sister and the brother transgress this taboo; because the mother and the son do not recognize one another as a result of the child being far from the social relation chain, they engage in a socially unacceptable relationship. This has led to a more severe condemnation of the transgression of the incest taboo between sister and brother in the tale.

\section{References}

Abali, N. 2011. "Incest in folk narratives." Master's Thesis. Ankara: Bilkent University. Balaman, A. R. 2002. Marriage Relation Kinds (Social Anthropological Attitude). Ankara: Publishing Culture Ministry.

Biesele, M. 1995. “Oedipus in Bushman Folklore.” In Oedipus: A Folklore Casebook, edited by Lowell Edmunds and Alan Dundes, 39-41. Madison: The University of Wisconsin Press.

Dundes, A. 1997. From Game to War and Other Psychoanalytic Essays on Folklore. Lexington: The University Press of Kentucky.

Eerola K. A. 2019. "The Oedipus myth and its analogues, especially its characteristic manifestation in Finnish folk tales." The Scandinavian Psychoanalytic Review 42:103-111.

Havilland W. A. 2008. Cultural Anthropology. Translated by Inan Deniz. Istanbul: Kaknus Publishing.

Karpati, M. 1995. "An Oedipus Myth in Gypsy Tradition." In Oedipus: A Folklore Casebook, edited by Lowell Edmunds and Alan Dundes, 23-28. Madison: The University of Wisconsin Press.

Lessa, W. A. 1995. "Oedipus-Type Tales in Oceania." In Oedipus: A Folklore Casebook, edited by Lowell Edmunds and Alan Dundes, 56-76. Madison: The University of Wisconsin Press.

Masson, J. M. 1985. The Complete Letters of Sigmund Freud to Wilhelm Fliess, 18871904. Cambridge: Harvard University Press.

Rustamov R. Ә. and Shiraliyev M. Ş. 1967. West group dialects and accents of the Azerbaijani language. Baku: Academy of Sciences.

SMOMPK. 1890. "Collection of materials for location details and tribes of the Caucasus." Tbilisi 9 (2):184-189.

Spiro, M. E. 1995. "The Oedipus Complex in Burma." In Oedipus: A Folklore Casebo$o k$, edited by Lowell Edmunds and Alan Dundes, 203-215. Madison: The University of Wisconsin Press.

Southall, A. W. 1995. "Oedipus in Alur Folklore.” In Oedipus: A Folklore Casebook, edited by Lowell Edmunds and Alan Dundes, 35-39. Madison: The University of Wisconsin Press. 
Safa Garayev

Institut za folklore. Nacionalna Akademija nauka Azerbejdžana

Tip edipovske priče u azerbejdžanskom folkloru i njena socio-psihološka semantika

U ovom radu priče sakupljene sa azerbejdžanskih teritorija analiziraju se iz psiho-semantičke perspektive, koja se odnosi na tip edipovskih priča (AT: 931, 933). Tabu incesta, koji je česta tema u azerbejdžanskom društvu, u ovim pričama se obeshrabruje kroz simbolička ponašanja. U ovim pričama, prikupljenim u različitim vremenima sa različitih azerbejdžanskih teritorija, kršenje tabua incesta prvo se događa između brata i sestre, a zatim između majke i sina. Kada se bajkovitim radnjama ovih priča pristupi u kontekstu edipovskog kompleksa, postaje jasno da su ove bajke takođe organizovane na osnovu tačke gledišta sina. Ovo je očigledno jer su u pričama očevi - česti likovi u pričama edipovskog tipa - prikazani kao krivci za sve antisocijalne i neetičke probleme.

Ključne reči: tip edipovskih priča, tabu incesta, tačka gledišta sina

\section{Le type de conte oexdipien dans le folklore azerbaijanais} et sa sémantique socio-psychologique

Dans cet article les contes collectés sur les territoires azerbaijanais sont analysés dans une perspective psycho-sémantique, en rapport avec le type des contes œdipiens (AT: 931, 933). Le tabou de l'inceste, qui est un thème fréquent dans la société azerbaijanaise, est découragé dans ces contes à travers des comportements symboliques. Dans ces contes, collectés à des époques différentes et provenant des territoires azerbaijanais différents, la transgression du tabou de l'inceste a lieu d'abord entre le frère et la sœur, puis entre la mère et le fils. Lorsqu'on aborde les fabuleuses actions de ces contes dans le contexte du complexe d'Edipe, l'on aboutit à la conclusion que ces contes sont organisés du point de vue du fils. Ceci est évident car dans ces contes les pères - personnages fréquents dans les contes du type oedipien - sont représentés comme coupables de tous les problèmes antisociaux et immoraux.

Mots clés: type de conte œdipien, tabou de l'inceste, point de vue du fils

Primljeno / Received: 20.09.2020

Prihvaćeno / Accepted: 30.12.2020 